\title{
細胞運命決定機構を明らかにする シングルセル遺伝子発現解析
}

\author{
坂本 智子 ${ }^{1)}$, 前 伸一 $^{2}$ ), 長船 健二 ${ }^{2)}$, \\ 岡田 千尋 ${ }^{1)}$, 樺井良太朗 ${ }^{1)}$, 渡辺 亮 ${ }^{1)}$
}

要約 : ヒトを構成する細胞は, 教科書的には 300 種類 以上あると言われてきたが，近年のシングルセル遺伝 子発現によって，これまで同一と考えられてきた細胞 種のなかにも不均一性があることが示され，少なくと も数千種類におよぶ細胞が存在することが明らかと なったこのような多種多様な細胞は 1 個の受精卵か ら発生するが，この多様性を生み出す運命決定機構は 未だ不明なことが多い. 分化・発生メカニズムを解き 明かすためには，各過程における個々の細胞の挙動を 正確に捉えることが必要不可欠である．現在，シング ルセルの単離およびcDNA合成をマイクロフルイディ クスや油中水滴型ドロプレットを用いて自動化した機 器が市販され, 多細胞を低コストで解析できるシング ルセル RNA シーケンスが爆発的に普及している。こ れらのシングルセル解析は, 細胞ごとの遺伝子発現パ ターンの比較を行うことで, 従来法では難しかった 個々の細胞の「不均一性の検出」および「擬似時系列 解析」を可能とし, 細胞分化過程を描写する有用な手法 となっている。 今回, これからシングルセル解析を始 めようと思っている研究者向けに, シングルセル RNA シーケンスの特徵をまとめた。 どのプラットフォーム も一長一短があるため, それらを十分理解した上で, 解析対象の細胞に合った手法を選択することが，より 良い結果を得るためにも必要不可欠である。 また, 後 半では, iPS 細胞から胎生期の腎前駆細胞である尿管 芽へ分化させる培養系を用いて, 分化誘導過程におけ る遺伝子発現をシングルセルレベルで解析した具体例 を示しつつ,これらの解析で得られた知見を培養系へ フィードバックし，効率的かつ選択的な尿管芽の作製 方法の確立に成功した一例を紹介したい.

\section{1. シングルセル遺伝子発現解析で迫る細胞の 多様性と階層性}

ヒトは一つの受精卵から発生し，厳密な時空間的制 御のもと, 数百種類以上の細胞が生み出される.この ように, 同じゲノム DNA, すなわち同一の遺伝情報を 持つにもかかわらず，多様な細胞種が生み出されるメ カニズム, すなわち細胞の性質を決定する遺伝子発現 制御を明らかにすることは, 長らく発生研究の重要な 課題の一つであった(1)。これらを調べる手法として, マイクロアレイ解析や RNA シーケンスによる網羅的 な遺伝子発現解析が行われてきたが，これらの手法は 数千個以上の細胞から抽出されたRNA を解析対象と しているため, 複数の細胞集団の平均的な転写状態を 反映した結果が得られるだけであった。 これに対して, 近年のシングルセル RNA シークエンシング（single cell RNA sequencing：scRNA-seq）は，一細胞におけ る遺伝子発現プロファイルを取得することで, 細胞の 個性を明らかにするだけでなく, 実験に用いる細胞数 に限りがある場合でも解析ができる有用なツールと言 える. 実際, 極めて入手が困難な初期発生肧を対象に した遺伝子発現解析も scRNA-seqで行われており(2), scRNA-seq は生物学実験の可能性を大きくひろげる ツールとして汎用されている.

scRNA-seq の研究対象は主に細胞集団解析, 擬似時 系列解析, 3D 再構築に分類される (3) (図 1). 細胞の 分類については, 複数の表面抗原に対する抗体でラべ ルを行ったのちにフローサイトメトリーで解析する方 法が広く行われているが，この方法では非常に少ない 細胞数の集団を捉えられる一方で, 細胞を分類するた めの表面抗原があらかじめ明らかになっていること, そして解析対象分子に対する特異的な抗体が存在して いる必要があり, また同時に解析できる抗原も数種類 
に限られる。最近は多数の抗体を同時にラベルする CyTOF (4) も開発されたが，細胞を分類する抗原を 知っておく必要があること，その抗原を特異的に認識 する抗体も依然必要である。一方，scRNA-seq による 細胞の分類は, 検出可能な全ての遺伝子の発現パター ンから類推するため, 細胞分類に必要な遺伝子や抗原 をあらかじめ決める必要がなく，抗体の有無の心配も 不要である。ささに, 細胞集団間で異なる発現を示す 遺伝子群の解析を行うことで, 細胞集団特異的なシグ ナルの同定が同時に行える。実例として，空間内にお ける細胞や組織の立体配置から議論されてきた大脳皮 質の細胞分類において, 3000 細胞で行った scRNA-seq では，6層構造における遺伝子発現の違いが確認でき た他，少なくとも 47 種類の細胞が存在することが示 唆された (5)。脳の構造のみならず，膵臓(6)，精巣 $(7)$, 網膜 (8) などの組織でも報告がなされ, scRNA-seq に よる細胞分類の流れが加速している。また， scRNAseqでヒトを構成する細胞の遺伝子発現プロファイル をデータベースにすることを目的に設立された国際コ ンソーシアムである Human Cell Atlas（HCA）がまも なく公開するデー夕によって細胞の多様性が明らかに なる。

scRNA-seq による個々の細胞の遺伝子発現の違いを 利用したアプローチは, 細胞分類のみならず, 発生過程 などの細胞の遷移状態の解析も可能である. scRNA-seq では, 実験時に細胞を破砕するために経時変化を観察 することは不可能であるが, 転写状態の類似性に基づい て細胞を並び替えることで，擬似時間軸（pseudo-time course）を定義し，細胞分化の軌跡を描くことができ る(9)。この手法では，実験における細胞回収日なと の時間情報を含めた事前知識を与えずに, 個々の細胞 の転写情報のみで並び替えを行うため, 生物学的な意 義に対応した細胞の並び替えが行えるのが大きな特徵 である。また，細胞分化の分岐点を同定することも可 能であり (10), 細胞運命の決定機構を解明するッール として活用されている.このような細胞の階層性の研 究に加えて, 細胞間相互作用や立体的な配置を推測す る研究(11-13) やアリルごとの発現を観察する試み （14）も進んでいる.

\section{2. シングルセル RNA 解析の手法}

現在，scRNA-seq を行う手法は複数報告されており， 細胞の分離，逆転写および cDNA 合成，そしてシーク エンシングライブラリの作製の各ステップでそれぞれ 異なる方法が開発されている。 シングルセルの単離は, マイクロフルイデイクス, マイクロウェル, そして油
中水滴型ドロプレットを用いた方法が主に行われてい る。逆転写からライブラリ作製も様々な方法があるが, mRNAの全領域をシークエンシングする方法（whole transcript amplification：WTA）か 3 末端や 5 末端のみ を標的にしたエンドカウント法かによって，解析方法 や出力される結果が大きく異なってくる。一般的に, スプライスバリアントや融合遺伝子の検出，アリルご との発現解析，未知の転写産物の探索などを目的とす る場合は WTA 法を，遺伝子発現の量的な解析の場合 はエンドカウント法を選択することが多い，また，WTA 法は，解析できる細胞数が少ないが，データクオリ ティが高く, エンドカウント法は, 解析できる細胞数 が多いがデータクオリティが低い傾向があるが，全長 をシーケンスしないエンドカウント法は，より少ない コストでより多くの細胞の定量解析が行えるというメ リットもある。.以上の特徵に加え，どれくらいの細胞 数を解析する必要があるのか，1細胞あたり何遺伝子 検出する必要があるのかなどを想定することで，解析 に適した手法をある程度絞り込むことができる．最近 は, polyAを持たない non-coding RNAも高い信頼度で 解析できる手法も報告されている(15)。ささらに，より 高い定量性を実現するために，解析対象の遺伝子をし ぼった Rhapsody (Becton, Dickinson and Company) な ども市販されている.

\section{3. 発生過程を可視化するシングルセル RNA 解析}

我々は, scRNA-seq が細胞の多様性と階層性を明ら かにする有用なツールであることに注目し，ヒト iPS 細胞からの分化過程を解析しているが，本稿では腎臓 への分化過程を解析した結果の一部を紹介する。腎臟 は，老廃物の排泄，体内の水分量の調節，電解質濃度 の調整，ホルモン産生などを担う臓器である。これら は生命を維持していく上で重要な機能であるが, 一度 失われた腎機能は, 多くの場合回復することなく, 末 期慢性腎不全に進行する。薬物療法による改善が期待 できないことから，透析治療や腎移植が必要となるが, 透析治療は負担が大きく, 腎移植に必要なドナー腎臓 も十分にないことから，人工的に作製された機能性腎 組織の移植が期待されている.

ヒトの腎臓は，左右それぞれ約 100 万個のネフロン で構成され, ネフロンは, 数本の毛細血管が球状に絡 まった小さなろ過装置である糸球体と, 糸球体から繋 がる尿細管からなり，尿細管はさらに集合管へと続く. このように構成する細胞が多種にわたる腎臟は, 多能 性幹細胞から作製が試みられている臓器の中でも最も 難易度の高いものの一つである. 
細胞分類

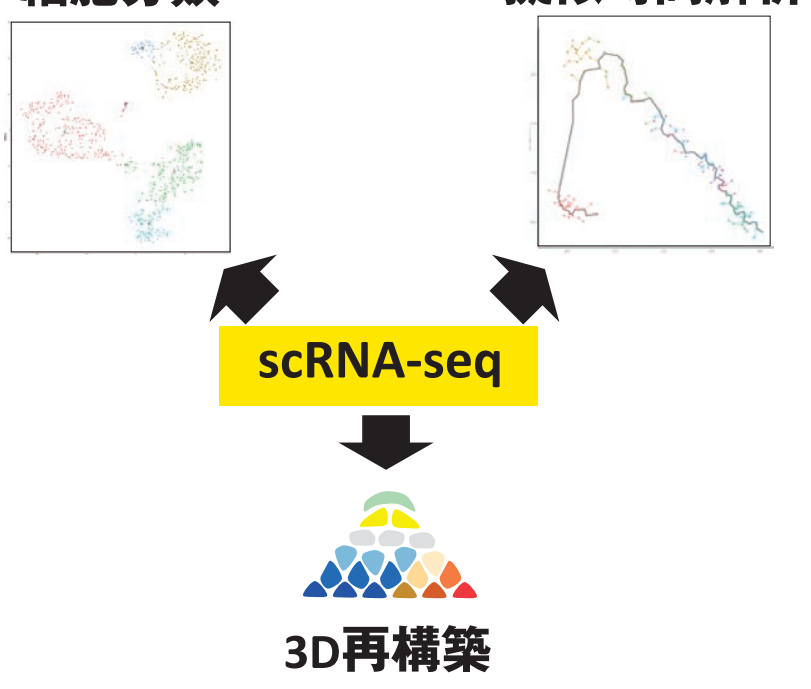

腎臓の発生では, 胎生初期組織の一つである中間中 肧葉に由来する尿管芽と後腎間葉の二種類の前駆細胞 の相互作用を経て臟器が形成される。尿管芽はおもに 集合管と下部尿路に, 後腎間葉はネフロンと間質へと 分化する．我々はヒト iPS 細胞から尿管芽を作製する 方法を確立した(16)。その際，分化誘導過程における 遺伝子発現プログラムの変化を捉え, ヒト腎臓の発生 過程の一端を明らかにすると共に, さらに効率的かつ 選択的に尿管芽を作製する培養条件を確立する目的で scRNA-seq を実施した。まず，ヒトiPS 細胞に Activin A, CHIR99021 を含む培地で培養することで原始線条へ と分化させた。ささらにレチノイン酸などを含む培地で 培養することで，尿管芽細胞の前駆細胞である GATA3 陽性の前方中胚葉を得た（図 2)。この各過程における

図 1 scRNA-seq データを用いた応用例

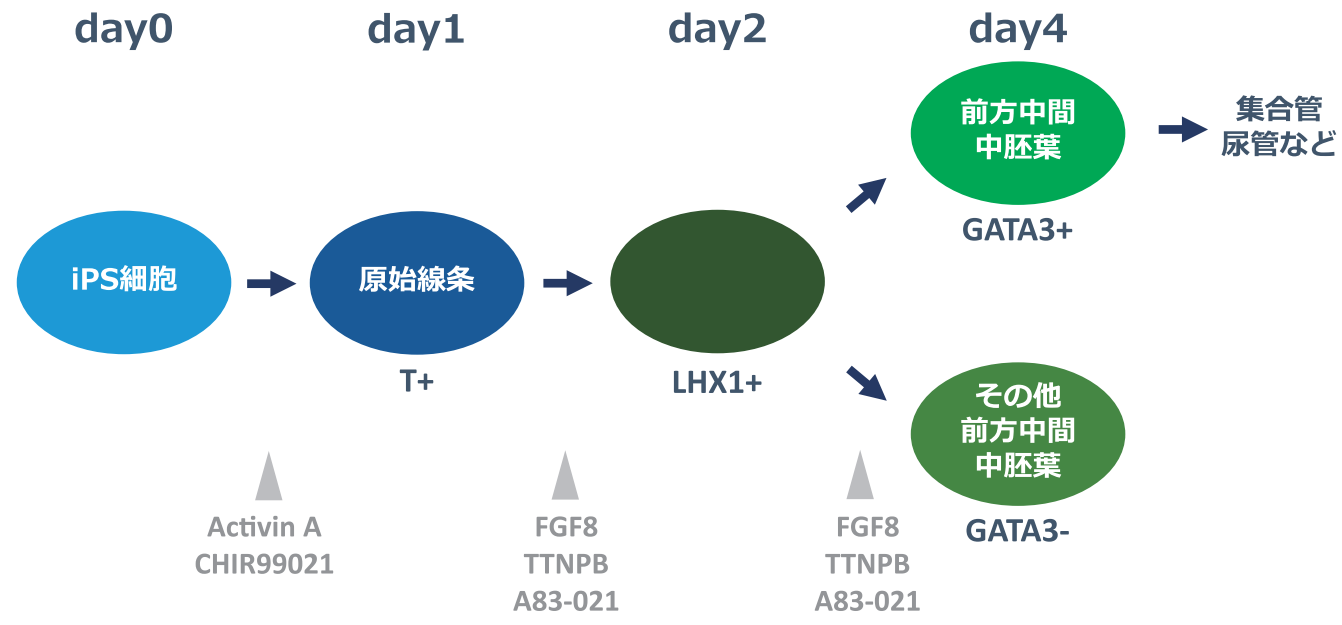

図 2 ヒト iPS 細胞から尿管芽への分化系

本研究で実施した iPS 細胞から前方中間中胚葉までの分化方法と分化マ一カ一遺伝子を示している. scRNA-seq は Dayl, 2, 4 の細胞に対し て実施した。
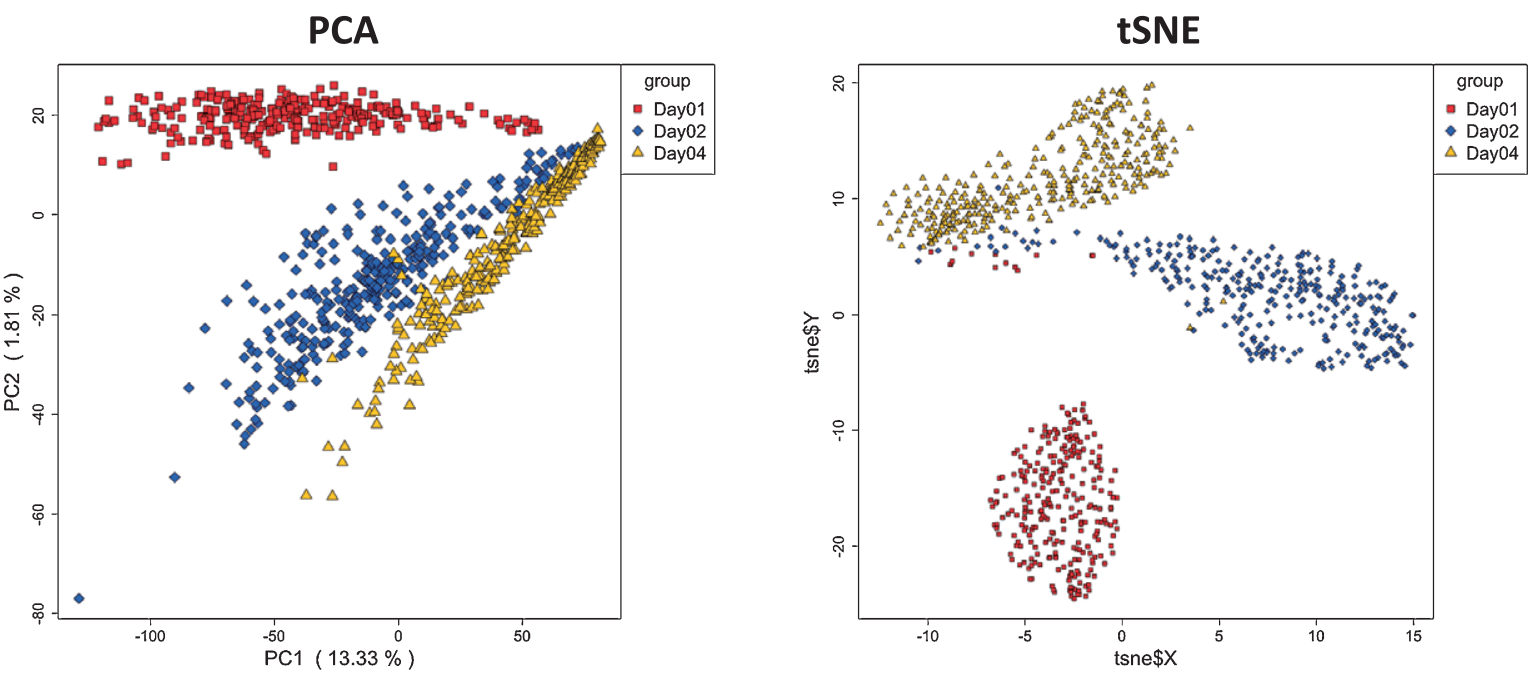

図 3 PCA 解析と tSNE 解析

分化誘導過程における細胞に対して scRNA-seq を行い, 異なる次元圧縮法を用いて細胞分類を行った結果, PCA に比べ, tSNE は細胞集団 をより明確に分類する傾向がみられた。多くの細胞はその回収日でサンプルが分類されるが，一部の細胞で異なる回収日にサンプルが分類され ていることが示された。 
細胞を回収し，イルミナ社の SureCell WTA 3’ Library Prep Kit及びドロップレット型のcDNA合成装置 (Bio$\operatorname{Rad}$ 社， ddSEQ）を用いて，シングルセルに由来する cDNA ライブラリを作製した。超並列シークエンシン サーを用いて，このライブラリに含まれる遺伝子の発 現量を定量化した結果, 各培養条件において 281〜321 個の細胞に対する遺伝子発現情報が得られた。まず, 主成分分析 (principal component analysis：PCA) $(17,18)$ およびtSNE (t-distributed stochastic neighbor embedding) 解析 (19) によって細胞同士の遺伝子発現状態の近似 性を評価することで細胞の多様性を可視化した．多く の細胞はサンプルの回収日に従って分類された一方で, 一部のサンプルは異なった回収日の細胞集団に属して いた（図 3)。この結果は, 同一の細胞集団の中におけ る分化状態に多様性があることを示唆していた。そこ で，最小全域木（minimum spanning tree）のアルゴリ ズムを用いた Monocle(9) によって遺伝子発現状態が 近い細胞を関連づけさせることで, 分化状態に対応させ た細胞の並び替え（擬似時間軸， pseudo-time course） を行った。 その結果, dayl から day4への分化に従って 細胞サンプルを並び替えることに成功した（図 4)。そ のサンプルの並びは, 基本的に day1, day2 そして day4 の順であったが，一部別の細胞集団の分化状態 に近い細胞が観察された。すなわち，この方法は，サ ンプルの取得日でサンプルの性質を評価するのではな

annotation - Day01 - Day02 - Day04

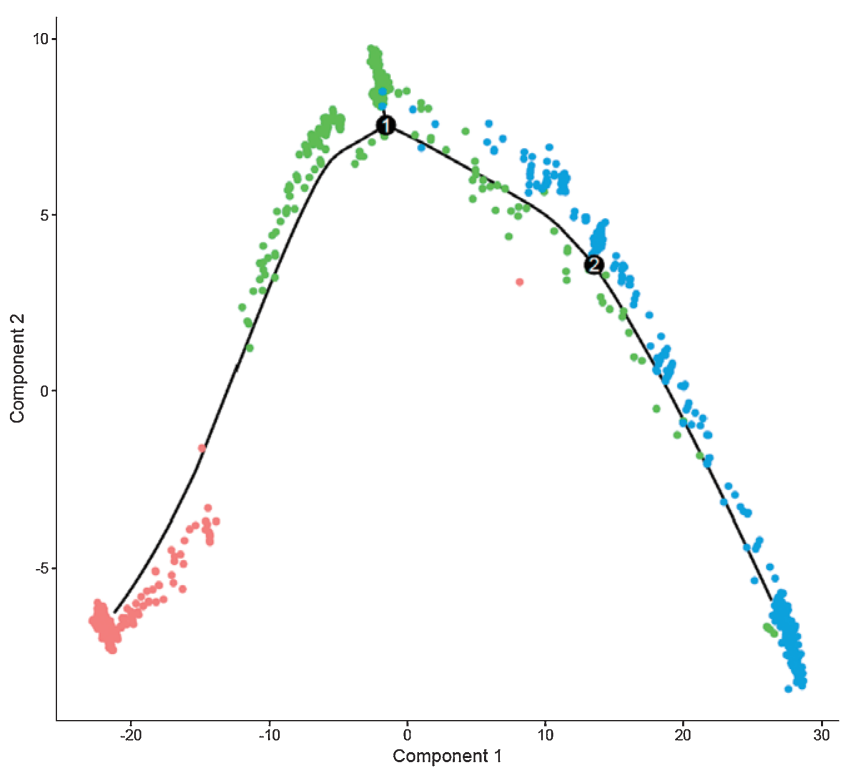

図 4 擬似時系列解析

遺伝子発現の類似性に基づいた細胞サンプルの並び替えを行った結果, 分化誘導期間に従つた並び替えが行われ，その分化方向は一つであるこ とが示唆された。同じ分化誘導期間でもその転写状態に多様性があり 異なる分化状態の細胞が共存していることが示された.
く, 細胞の分化状態で解析が可能になったことを示し ている。 この擬似時間軸上で発現が変動する遺伝子を 抽出すると，分化に従って一方向で発現が低下または 六進する遺伝子群のみならず，一過的に発現が変動す る遺伝子群を捉えることに成功した（図 5). 次に, 我々は分化過程で発現が立進する遺伝子群の中に，尿 管芽形成を促す因子があると仮定し，分化促進因子の

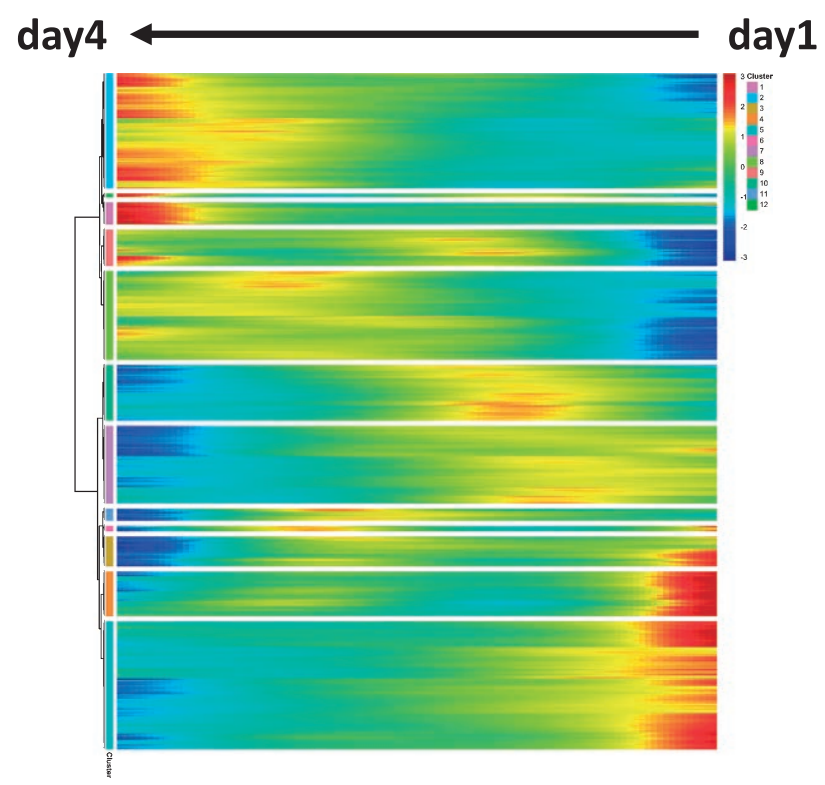

図 5 擬似時系列解析を用いた全遺伝子のクラスタリング Monocle2 を用いて，擬似時系列上で類似した発現变動パターンを示す 遺伝子群をクラスタリングした。初期に発現が高い遺伝子群, 後半で発 現が上昇する遺伝子群，一過性に発現が上昇する遺伝子群などが可視化 された．赤は発現が高く，青は発現が低しことを示す。

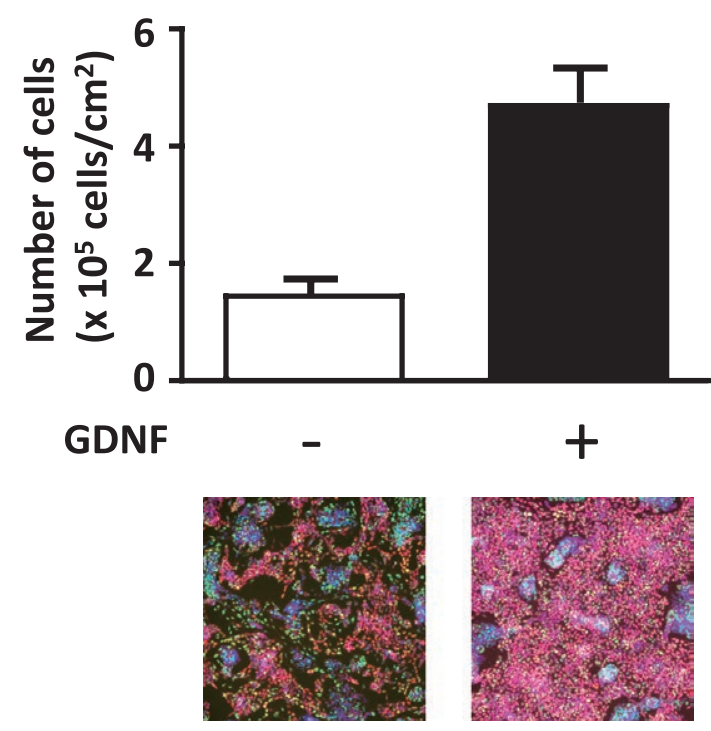

Ki67 GATA3 Nuclei 図 6 栄養因子 GDNF の添加により，GATA3 陽性細胞の増殖が 3.3 倍に促進

解析で得られた知見を培養系へフィードバックすることで, より効率的 かつ選択的に尿管芽細胞が作製できた。 
探索を行った．培養上清に添加することを考慮して， GATA3 と発現が相関する遺伝子の中で, その局在が 細胞外である因子の探索を行った，その結果，10\%程度 の GATA3 陽性細胞に特異的に発現する栄養因子 GDNF （glial cell line derived neurotrophic factor）を同定した. 実際，GDNF を培養系に加えたところ，GATA3 陽性 細胞の増殖を 3.3 倍に促進できた（図 6). 複数の細胞 が存在する集団から興味のある細胞を同定し, その細 胞が増殖する条件を見いだすことを可能にしたこの手 法は, 他のシングルセル遺伝子発現で行われている経 時的な転写ネットワークの変化の擬似的な描写や新規 の細胞種の同定とは異なる応用的手法である。同様の 解析は細胞集団を対象にした従来の方法では極めて難 しく, シングルセル RNA シークエンシングがもつ大 きな特徴の一つと言える。このように, 同じ scRNAseq デー夕を用いて, 異なる解析を行うことで, 細胞 集団や擬似時系列，そしてシグナルネットワークを明 らかにできるなど, 様々な展開が可能であることが示 された．また，多数の細胞サンプルで解析するため, 少数の細胞を対象にした遺伝子発現解析や一過的に遺 伝子発現が変化する細胞の同定ができることは scRNA-seq がもつユニークな特徴である.

\section{4. まとめと今後の展望}

シングルセル RNA 解析では, 擬似時系列解析を用 いることで，これまで実験日で分類していた細胞を， 生物学的な意義（例えば分化状態）に対応させて並び 替えたり, 不均一性を検出することで, 従来法では観 察できなかった細胞集団や, バルクの RNA-seq では検 出不可能なわずかな細胞集団の特性を捉えたりするこ とが可能となった。しかしながら, 組織由来の細胞で は, 1 細胞あたりの平均検出遺伝子数が低い傾向にあ るなど問題点も残る。我々の経験から, 解析結果の質 を大きく左右するのがライブラリの質であり，それは シングルセル化した時の細胞の質, 生存率に大きく依 存することが分かっており, 現在市販されているプ ラットフォームを用いる場合, 最低でも $60 \%$ 以上の細 胞生存率は確保すべきと考えている。組織から解析に 耐えうるシングルセル懸濁液を調整することは意外と 困難なため, シングルセル RNA 解析を始める前に十分 条件検討を行うべきである。 また，シングルセル単離 までの時間, 試薬の種類や濃度, 試薬内に置かれてい
た時間, 温度, 細胞の凍結などによっても遺伝子発現 は影響を受けるため, 注意が必要である。ささらに, 稀 少な細胞種を対象にする場合は, より多くの細胞数か らスタートする方が望ましい。また，1回の実験コス トが高額な点も, シングルセル解析の普及を妨げる要 因となっており, 今後コストを低下させる技術の開発 が待たれる。

本稿では, 遺伝子発現解析を中心としたシングルセ ル解析について，我々の事例及び既報を紹介した。こ の他に, ゲノム変異や DNA コピー数を解析するシン グルセル DNA 解析や, 転写活性化を受けているオー プンクロマチン領域を解析する方法も報告されている. さらに, DNA と RNA を同時に解析する手法も報告さ れるなど，シングルセル解析の適用範囲が広がってい る. 一方で, 解析対象となる細胞数が数千, 数万単位 になってきて, 出力されるデー夕量も膨大になってお り, 従来と異なる解析アプローチが求められている. このような数理解析の開発も今後のシングルセル解析 の発展に重要な役割を果たすだろう.

謝辞 : 筆者らの研究は, 科学研究費「特設分野研究（構成的 システム生物学) 」, 科学研究費「若手 $\mathrm{B}\rfloor$, 日本医療研究開 発機構 (AMED) の再生医療実現拠点ネットワークプログラ 厶「iPS 細胞研究中核拠点」,「技術開発個別課題」および難 治性疾患実用化研究事業により, 助成を受けたものである.

著者の利益相反 : 長船健二 (大塚製薬株式会社), 岡田千尋 (三菱スペース・ソフトウエア株式会社).

\section{文献}

1) Moris N, et al. Nat Rev Genet. 2016;17:693-703.

2) Guo G, et al. Dev Cell. 2010;18:675-685.

3) Hwang B, et al. Exp Mol Med. 2018;50:96.

4) Bandura DR, et al. Anal Chem. 2009;81:6813-6822.

5) Zeisel A, et al. Science. 2015;347:1138-1142.

6) Baron M, et al. Cell Syst. 2016;3:346-360.e4.

7) Green CD, et al. Dev Cell. 2018;46:651-667.e10.

8) Macosko EZ, et al. Cell. 2015;161:1202-1214.

9) Trapnell C, et al. Nat Biotechnol. 2014;32:381-386.

10) Treutlein B, et al. Nature. 2014;509:371-375.

11) Takebe T, et al. Nature. 2013;499:481-484.

12) Halpern KB, et al. Nature. 2017;542:352-356.

13) Satija R, et al. Nat Biotechnol. 2015;33:495-502.

14) Deng Q, et al. Science. 2014;343:193-196.

15) Hayashi T, et al. Nat Commun. 2018;9:619.

16) Mae SI, et al. Biochem Biophys Res Commun. 2018;495:954-961.

17) Pearson K, et al. Philosophical Magazine. 1901;2:559-572.

18) Hotelling H, et al. Journal of Educational Psychology. 1933;24: 417-441, 498-520.

19) van der Maaten LJP, et al. Machine Learning. 2012;87:33-55. 


\title{
Dissecting early development of the kidney by single cell transcriptomics
}

\author{
Satoko Sakamoto ${ }^{1)}$, Shin-ichi Mae ${ }^{2)}$, Kenji Osafune ${ }^{2)}$, Chihiro Okada ${ }^{1)}$, Ryotaro Kabai ${ }^{1)}$, \\ Akira Watanabe ${ }^{1)}$ \\ ${ }^{1)}$ Department of Life Science Frontiers, Center for iPS Cell Research and Application, Kyoto University \\ ${ }^{2)}$ Department of Cell Growth and Differentiation, Center for iPS Cell Research and Application, Kyoto University
}

\begin{abstract}
Each of the billions of the cells in our body exhibits their identity with unique gene expression profile. Recent advances in single cell transcriptomics enable to conduct cell taxonomy identifying new cell types and to re-arrange cells in order of pseudo-time course describing differentiation status of each cell. Even though the cost is still high, the single cell transcriptomics now becomes one of the conventional assays. We have applied the single cell gene expression analysis to dissect human development. In this article, we show our recent progress on a study describing early development of the kidney using human iPS cells by the single cell transcriptomics.
\end{abstract}

